\title{
4
}

\section{Customary land tenure and common/ public rights to minerals in Papua New Guinea}

\author{
Andrew A.L. Lakau
}

Throughout Papua New Guinea a wide range of natural resources or substances were extracted from land, sea and waters, using a variety of techniques. In coastal areas coral reefs, shells and other marine resources have always had great value. In the highlands, there is widespread evidence of stone quarries and other extraction sites which were worked on for thousands of years. Haynes (1995:33) summarises the evidence on the use of natural resources

for pre-colonial trade, significant sub-surface substances were extracted for use in the manufacture of items for trade, or for trade in their original form. These included mineral pigments of various kinds, edible earth (a dietary supplement of pigs), various kinds of stone and clay (for pottery and other purposes). Furthermore, water from mineral springs was used to make salt and mineral oil from seepage was used as a cosmetic, medicine and possibly as cooking fuel. Stone was the substance most extensively extracted, being used for many purposes which included cooking stones, hammer and anvil stones, drill points, awls, scrapers, knives, bark cloth beaters, axe blades and prehistoric mortars and pestles and naturally weathered curiously shaped stones were used in magico-religious rituals.

There were also claims to the exploitation and ownership of natural resources. At times, there were conflicting claims asserted by neighbouring groups over these resources or substances. The rights to use particular 
natural resources were guided by rituals and laws which developed alongside the discovery of these resources. In the postcolonial period, these traditional laws have been subsumed by what could be termed 'Western' law. Peter Sack argues for a distinction between what he terms 'primitive' law and 'Western' law

Primitive law being an open system, it cannot be argued that no rights to rock outcrops and patches of poor soil exist because the traditional law says nothing about them (as could probably be argued in Western law). Although not yet defined, these rights will be defined when their existence becomes a practical issue. This definition does not create new rights; they existed all the time, only in a latent form (Sack 1973:20).

Both law and custom are subject to constant adjustment in space and time. It is inevitable that custom has changed in reaction to postcolonial settlement and contemporary circumstances with respect to mineral rights.

Minerals, oil and gas can be seen in two ways. First, they are resources of value which naturally occur. In this case, ownership, and the right to use such resources would belong to the landowners. Second, minerals, oil and gas can be perceived as other natural resources such as rivers and lakes-as public or common property. In this case, landowning groups are merely trustee administrators.

From a societal point of view, there is some justification in the state maintaining ownership rights over minerals and other natural resources without traditional value or use. There is a valid argument in the Papua New Guinea situation that resources of immense economic value should not be left to particular individuals or communities. Ownership of such valuable natural resources should be vested in the state, in the same way as ownership of customary land is vested in the clan or kinship group as a whole. Both such authorities exercise their roles on a trustee basis, one (the state) for the whole society and the other (the landowning group), for its members.

Today, the nation-state of Papua New Guinea encompasses all existing tribal groups. The challenge lies in reconciling this modern state and the numerous tribal societies that had previously performed many of roles of a nation-state. However, wholly reinstating such traditional political units would be inconsistent with nation-building and anti-constitutional as well.

I believe that society as a whole has a right to share in whatever socioeconomic advantages flow from the development of mineral 
resources. Parties in a mining deal should not just be the mining company and the customary landowners. The state as custodian of the public interest must regulate the deal on behalf of society as a whole, as well as derive its own share of benefits. At the same time, it is the state which can guarantee security on an investment, ensuring fair bargaining and benefits to either side.

The best scenario is one where there is maximum benefit flowing from mining development to society as a whole and the customary landowners. Such a scenario must also continue to attract the necessary commitment from foreign investors and mining corporations who have the expertise and capital essential for continued development of mineral resources in Papua New Guinea.

In democratic States, where governments are representative of the whole society, the value of minerals far exceeds individual or sectional interests. To favour the interest of a minority or sectional group would lead to situations similar to that in the Middle East. There, the vast wealth generated from oil and petroleum is siphoned by a few individuals at the expense of the impoverished masses.

The community or individuals in whose land minerals are found can benefit by way of compensation, royalty payments and various forms of income (Lakau 1995, Haynes 1995). Environmental considerations can be part of that compensatory package. These are provided for all small to large-scale mining operations in Papua New Guinea.

To leave the right of ownership of mineral resources entirely to customary landowners is dangerous. Although this may be acceptable in other countries, in Papua New Guinea, it is likely that this would open the floodgates for numerous claims to gain exclusive benefits from commercial mining, leading to disharmony between those who have the happy accident of minerals under their land, and most, who do not. Private landowners, in the name of customary rights, would try to dictate terms to legitimate governments and society as a whole. Private ownership of minerals would also lead to 'veto', where the landowners may refuse development of mineral resources under their land, virtually holding society to ransom.

Customary landowners cannot be 'free-riders' on other benefits they derive from society. It is largely because of the efforts of society as a whole that land has an economic value. Public funding provides the social and economic infrastructure-roads, bridges, public safety or security, markets, and finance-which enables the utilisation of land and mineral resources. 
Private and communal landownership confers on sectional groups the right to profit from public actions in which they have played no part. Such private property rights may be argued as constitutional rights. But when rights are concentrated in the hands of sectional and selected groups, this is an abuse of private property. Speculation, manipulation, concentration of wealth and the like are not desirable and were never the dreams of Papua New Guinea's founders.

Individuals and communities within the nation-state cannot enjoy other privileges and subsidiary rights flowing from them, without the state at large safeguarding everyone's interests. Hence, even customary rights are not persuasive in claims to exclusive possession of minerals on or under their land.

Moreover, customary land tenure systems in Papua New Guinea have clearly demarcated reference to individual, community and public or common property rights. Advocacy of exclusive possession carries connotations of greed, and is arguably alien to customary principles of land use and tenure.

\section{Conflicting roles of the state}

However, state ownership of minerals is only fine in so far as the state is representative of the common or public interest. What has turned out in practice in Papua New Guinea over the years leaves a lot to be desired and is a prime reason for the lack of development, the breakdown of law and order, and the masses being left out of the fruits of prosperity and nation-building (Dorney 1990, Holzknecht 1995).

The state has become an arena of conflict. Governments are supposed to manage resources such as minerals which belong to the State on a trusteeship basis. In Papua New Guinea, the governments see themselves as the state. Parliamentarians and bureaucrats have been prone to corruption and mismanagement (Dorney 1990, Holzknecht 1995). Individuals and groups who entered the arena of resource management via the parliament or government have made it an established practice to further private interests, either individually and for their factions. They use slogans such as 'the people', 'national interest' and 'privatisation', when in fact the real beneficiaries are those who wield power and control public coffers.

It is in the midst of these conflicting roles, corrupt practices and mismanagement that state ownership of minerals is being challenged. 
More often than not, the challenge is not over the logic or the legitimacy of state ownership of minerals-it is over the distribution of benefits flowing from the development of minerals.

\section{Conclusion}

On one hand, ownership of minerals is a right of the state. Legal challenges to state ownership of minerals have had no success in Papua New Guinea to date.

On the other hand, Papua New Guinea is a property owning democracy. It follows that customary landowners have unchallenged rights to ownership of their land and the development of resources found therein. However, the pursuit of national economic growth in Papua New Guinea can only be achieved with a pluralistic approach that contains a mixture of private and common property rights. Customary land tenure systems in themselves have connotations of individual, communal and public or common property rights. Any form of development should be for the benefit of people as a whole.

Instances where many are disadvantaged from development must be avoided. State ownership of minerals is part of common property interests. Customary principles do not necessarily conflict with state ownership of minerals. Only when a genuine and developmental state owns minerals will there be a facilitation of societal development. This is not the case in Papua New Guinea, and this is the fundamental but unresolved issue that is largely to be blamed for the lack of development and most of the people being left out of the mainstream of national growth and prosperity in mineral-rich Papua New Guinea.

\section{References}

Crocombe, R.G. (ed.), 1987. Land Tenure in the Pacific, University of the South Pacific, Suva.

and Hide, R., 1987. 'New Guinea: unity in diversity', in R.G. Crocombe (ed.) Land Tenure in the Pacific, University of the South Pacific, Suva:324-67.

- ( (ed.), 1995. Customary Land Tenure and Sustainable Development: complementarity or conflict?, South Pacific Commission, Noumea and Institute of Pacific Studies, University of South Pacific, Suva.

Dorney, S., 1990. Papua New Guinea: people, politics and history since 1975, Random House, Milsons Point. 